\title{
Comparison of in vitro-cultured and wild-type Perkinsus marinus. III. Fecal elimination and its role in transmission
}

\author{
David Bushek $^{1, *}$, Susan E. Ford ${ }^{2}$, Marnita M. Chintala ${ }^{3}$ \\ ${ }^{1}$ Baruch Marine Field Laboratory, Belle W. Baruch Institute for Marine Biology and Coastal Research, \\ University of South Carolina, PO Box 1630, Georgetown, South Carolina 29442, USA \\ ${ }^{2}$ Haskin Shellfish Research Laboratory, Institute of Marine and Coastal Sciences, Rutgers University, 6959 Miller Avenue, \\ Port Norris, New Jersey 08349, USA \\ ${ }^{3}$ United States Environmental Protection Agency (US EPA), Office of Research and Development (ORD), National Health and \\ Environmental Effects Laboratory (NHEERL), Atlantic Ecology Division, 27 Tarzwell Drive, Narragansett, Rhode Island
} 02882, USA

\begin{abstract}
Perkinsus marinus, a pathogen of the eastern oyster Crassostrea virginica, is transmitted directly among oysters. Previous studies found viable $P$. marinus parasites in the feces and pseudofeces of oysters within hours of injection with parasites, suggesting that the parasite may be voided from live oysters and subsequently dispersed in the water column. The experiments described here were designed to quantify $P$. marinus shed in the feces and pseudofeces of experimentally infected oysters. The results indicated that parasites were shed in 2 phases. A 'decreasing' phase occurred within $2 \mathrm{wk}$ of challenge and before net parasite proliferation began in the host. An 'increasing' phase occurred after $P$. marinus had begun replicating. The quantity of $P$. marinus recovered in the feces and pseudofeces of exposed oysters was only about $5 \%$ of the dose administered. In vitro-cultured $P$. marinus were eliminated at a greater rate than wild-type $P$. marinus and the fraction discharged was not associated with culture phase. Oysters that were continuously dosed with $P$. marinus in their food gradually lost the ability to discard the parasite in pseudofeces. The quantity of $P$. marinus shed in feces of infected oysters was correlated with both the $P$. marinus body burden and subsequent survival time, suggesting that noninvasive fecal counts could predict infection intensity and survival. The results indicate that in an epizootic, shedding of $P$. marinus via feces is relatively small compared to the potential number released by cadavers of heavily infected oysters, but that fecal discharge may be important in transmission before infections become lethal.
\end{abstract}

KEY WORDS: Disease $\cdot$ Parasite $\cdot$ Oyster $\cdot$ Crassostrea virginica $\cdot$ Infection $\cdot$ Modes of transmission

\section{INTRODUCTION}

Parasites are transmitted from host to host by a variety of methods ranging from direct contact to longrange transport by water or air currents (Cheng 1973, Fuxa \& Tanada 1987). In the case of highly lethal parasites, host death and disintegration typically release infective stages into the environment, but another

*E-mail: dbushek@belle.baruch.sc.edu important source of infective stages can be from the feces of a living, infected host (Andreadis 1985, Mortensen 1993, Côté \& Poulin 1995). For parasites that cause non-lethal infections, or during the period before the host's death, the latter may be the principal mode of release.

Perkinsus marinus, a highly contagious protistan parasite of the eastern oyster Crassostrea virginica, is transmitted directly from oyster to oyster (Ray 1954) and causes extensive mortalities in host populations. The onset of infections in newly introduced, uninfected 
oysters frequently coincides with $P$. marinus-caused deaths of native oysters. In addition, experiments in which positions of infected and uninfected oysters were fixed showed that mortalities due to $P$. marinus were accelerated in individuals near dead and dying infected oysters (Ray 1954, Andrews 1988). Decay of infected tissue, with consequent release of parasites into the water column, has thus been considered the main source of infective cells for $P$. marinus transmission (Mackin 1962, Andrews 1988).

Oyster deaths caused by Perkinsus marinus are seasonal, and typically highest in the late summer and fall; however, oysters can become infected earlier in the summer (Andrews 1988, Burreson \& Ragone Calvo 1996). Observations of an initial infection increase in June may be attributable to the proliferation of parasites that survived in vivo overwinter (Ragone Calvo \& Burreson 1994, Burreson \& Ragone Calvo 1996), but it is possible that some parasites are able to survive overwinter outside the host and can infect oysters as soon as the oysters begin to filter in the spring (Mackin 1962). Because oysters are metabolically active and parasites are proliferating rapidly in previously infected animals by this time (Bushek et al. 1994, Ragone Calvo \& Burreson 1994), another possible release mechanism could be the voiding of $P$. marinus in the feces, their dispersion into the water column, and their uptake by other oysters. This argument is supported by the report of Bushek et al. (1997), who found large numbers of viable $P$. marinus in the feces and pseudofeces of oysters within hours of injection with in vitro-cultured parasites. Andrews \& Hewatt (1957) also found $P$. marinus in oyster feces, but still considered oyster death to be the primary source of infective stages. Nevertheless, oysters with moderate to heavy infections can survive for prolonged periods (Saunders et al. 1993, Hofmann et al. 1995, Ford et al. 1999), and their continuous shedding of viable parasites could be an important means of transmission for this pathogen (Scanlon 1997).

The study reported here was intended to test the hypothesis that Perkinsus marinus are regularly shed in the feces of infected oysters and constitute a potentially important source of infective stages for parasite transmission. It was part of a set of experiments designed to assess virulence of cultured and wild-type P. marinus (Chintala et al. 2002, this issue, Ford et al. 2002, this issue). To help understand the interactions between host and parasite in these experiments, we collected feces and pseudofeces from individual oysters at regular intervals after challenge, determined parasite loads, and related them to the parasite densities in tissues of the live oyster as well as to time after challenge. The specific questions examined by feces/pseudofeces collection were: (1) Are cultured $P$. marinus handled differently by the oyster than wildtype P. marinus? (2) Does dosing method alter P. marinus release by the oyster? (3) Does culture phase of $P$. marinus alter parasite release by oysters? (4) Does acute versus chronic exposure to $P$. marinus alter parasite discharge by oysters? In a preliminary study Bushek et al. (1997) found evidence that oysters may be able to sort and reject parasites while feeding; therefore, the data collected in the present study allowed us to explore the hypothesis that oysters can recognize and discard $P$. marinus before they are ingested.

\section{MATERIALS AND METHODS}

Oysters. Hatchery-reared Crassostrea virginica, from the Damariscotta River in Maine, were shipped overnight to the Haskin Shellfish Research Laboratory and maintained in the laboratory at $10^{\circ} \mathrm{C}$ and $25 \mathrm{ppt}$ in $1 \mu \mathrm{m}$-filtered seawater (FSW) before the start of each experiment. Ten oysters were sacrificed initially and assayed to determine whether they were free of Perkinsus marinus infections (see Table 2 in Chintala et al. 2002). Before and during each experiment, oysters were fed a daily maintenance diet of approximately $2 \times 10^{6}$ cells of a 2:1 mixture of Isochrysis spp. and Chaetocerous spp. All experiments were conducted in FSW at 26 to $28^{\circ} \mathrm{C}$ and 25 ppt. Water was aer-

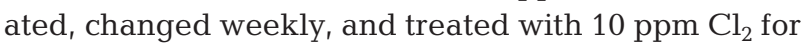
at least $24 \mathrm{~h}$ prior to disposal. All experiments were terminated after $84 \mathrm{~d}$, except the culture-phase experiment, which ended on Day 87. All surviving oysters were processed for total parasite burdens.

Comparison of cultured and wild-type Perkinsus marinus delivered by different dosing methods. Oysters were injected with either cultured or wild-type $P$. marinus by 1 of 4 delivery methods: feeding, intubation, shell-cavity injection, or adductor sinus injection (Chintala et al. 2002). Feces and pseudofeces were collected at intervals during the experiment to determine patterns and levels of parasite elimination associated with cell type and dosing method.

Parasites were obtained from in vitro culture or isolated from naturally infected oysters (Ford et al. 2002). All oysters, regardless of parasite type or method of delivery, were given a single dose of $10^{6}$ Perkinsus marinus per gram wet meat weight $\left(\mathrm{g}^{-1} \mathrm{wwt}\right)$. Meat weights were estimated by subtracting the weight of the oyster in water (i.e. the shell weight) from its weight in air (Andrews 1961). Twenty oysters were dosed by each method, 10 with cultured parasites and 10 with wild-type parasites. An additional 10 control oysters were not exposed to any P. marinus. The delivery time for each method was adjusted so that all oys- 
ters went into the water at the same time. After the dosing procedure, each oyster was placed in a 1.51 covered container with aerated water for the remainder of the experiment. Before the start of the experiment, 5 oysters in each treatment group were randomly selected for feces and pseudofeces collections on Days 1, 2, 7, 14, 28, 56, and 84. All feces samples were counted; however, only the Day 1, 2, 7 and 84 pseudofeces samples were counted.

Effect of in vitro culture phase. Perkinsus marinus from 3 culture phases (lag, log, and stationary) were obtained from Passage 4 of isolate LX-4 (Ford et al. 2002). The isolate was maintained at $22^{\circ} \mathrm{C}$ in Dungan's Medium (Bushek et al. 2000). Lag-phase cells were produced by diluting the density of cultured cells by $90 \%$ with fresh culture medium and then harvesting the cells needed after $24 \mathrm{~h}$. The log-phase cells were harvested from similarly diluted cultures $4 \mathrm{~d}$ after the dilution. The stationary-phase cultures were produced by allowing cultures to grow to maximum density while replenishing $50 \%$ of the culture medium weekly for $4 \mathrm{wk}$ prior to the experiment. When enumerating $P$. marinus from the 3 different culture phases, large meronts that contained many small merozoites where counted as 1 cell in the delivered dose. Parasites from each culture phase were administered via a single shell-cavity injection to 30 oysters, at $10^{6} \mathrm{P}$. marinus cells $\mathrm{g}^{-1}$ wwt (Ford et al. 2002). The oysters were then distributed equally among 151 buckets, each holding 10 oysters injected with the same cell type. Two replicate buckets of 10 oysters each were held as controls and did not receive any $P$. marinus cells. Feces and pseudofeces were collected from each bucket $(\mathrm{N}=3$ for each culture phase and $\mathrm{N}=2$ for controls) on Day 1 post-inoculation.

Comparison of acute vs chronic feeding. Thirty-six oysters were assigned to each of 2 Perkinsus marinus feeding treatments and 18 oysters were used as unchallenged controls. Each oyster was placed in aerated water in an individual covered, 1.51 container at the start of the trial. Oysters in the first treatment group (acute exposure) each received a single dose of $240 \times$ $10^{6} \mathrm{P}$. marinus cells mixed with their food at the start of the experiment. Each oyster in the second group (chronic exposure) received 24 equal doses of $10 \times 10^{6}$ $P$. marinus cells, mixed with food, for the first $8 \mathrm{wk}$ of the experiment $\left(3 \mathrm{wk}^{-1}\right)$.

Cultured parasites were harvested during the log phase of growth from the LX-4 isolate (Ford et al. 2002). They were transferred 20 times (from Passage 3 to Passage 23) during the experiment. Feces and pseudofeces were collected on Days 1, 28, and 56 postchallenge from oysters assigned to be sampled at Day 84, the conclusion of the experiment $(\mathrm{N}=6$ from each dosing regime and $\mathrm{N}=3$ controls). For the Day 28 and 56 samples in the chronic treatment, feces and pseudofeces were collected $24 \mathrm{~h}$ after dosing (feeding).

Sample processing. In all experiments, the water in the containers was changed and the oysters fed approximately $24 \mathrm{~h}$ before feces and pseudofeces collection, which thus comprised only material discharged over the preceding $24 \mathrm{~h}$. Feces and pseudofeces were collected separately using separate Pasteur pipettes. Material was placed in $15 \mathrm{ml}$ capped centrifuge tubes and allowed to settle overnight at $4^{\circ} \mathrm{C}$, after which excess fluid was decanted. Ray's fluid thioglycollate medium (RFTM) was added; this causes Perkinsus marinus to enlarge (Ray 1952). After 2 wk, the samples were centrifuged and washed with deionized water, which provided a relatively clean parasite suspension at a final volume of $2 \mathrm{ml}$. Three to four $100 \mu \mathrm{l}$ aliquots were counted as described by Fisher \& Oliver (1996) and averaged to determine the total number of parasites present. If average counts were $<20$ cells, the entire sample was counted. Final counts were expressed as parasites oyster ${ }^{-1}$. Oyster processing is described in Ford et al. (2002).

Statistics. Parasite densities were transformed $\left(\log _{10}[x+1]\right)$ and subjected to analysis of variance (ANOVA) using a general linear model in SAS (SAS Institute 1990). The Bonferroni post-hoc test was used for pairwise comparisons. Differences between means were considered significant at $\alpha=0.05$. Controls were not included in the models because the objectives examined differences between treatment types, not between treatments and controls. Correlation and regression analyses were used to investigate the relationships between parasite burdens in feces and (1) those in tissues and (2) days to death.

\section{RESULTS \\ Comparison of cultured and wild-type Perkinsus marinus rejection rates}

To facilitate visualization of parasite elimination over time, data from the various dosing methods were pooled by discharge compartment (Fig. 1A) or by parasite type (Fig. 1B). Elimination of parasites in both feces and pseudofeces declined rapidly from Day 1, with an average daily discharge rate of $10^{2.9}$ to $10^{3.4}$ parasites in the pseudofeces and feces, respectively, to only $10^{1.0}$ to $10^{1.6}$ by Day 7 (Fig. $1 \mathrm{~A}$ ). After Day 7 , the feces discharge of Perkinsus marinus rose steadily to a mean of $10^{2.8}$ by the end of the experiment on Day 84 . At the same time, the discharge rate of parasites in pseudofeces also increased, but to only $10^{1.7}$ parasites oyster ${ }^{-1} \mathrm{~d}^{-1}$. Over the first $2 \mathrm{~d}$ post-challenge, when the majority of cells were discarded, the total number of 
cultured cells eliminated in both feces and pseudofeces was consistently and statistically greater, by 1 to 1.5 orders of magnitude, than the number of wild-type cells. The difference decreased over time, and by Day 14 the numbers were similar (Fig. 1B). After Day 14, the quantity of parasites shed by oysters injected with wild-type parasites began to rise, whereas that voided by oysters dosed with cultured parasites remained almost static for an additional 5 wk before it, too, began to rise. This difference was observed in both feces and pseudofeces (data not shown). During the first $2 \mathrm{~d}$ after dosing, $3.6 \%$ of all cultured and $0.11 \%$ of all wild-type $P$. marinus (untransformed numbers, a 35:1 ratio) were expelled as viable parasites (viability based on ability to enlarge in RFTM).

An effect of dosing method was observed on the quantity of parasites shed in the feces and pseudofeces

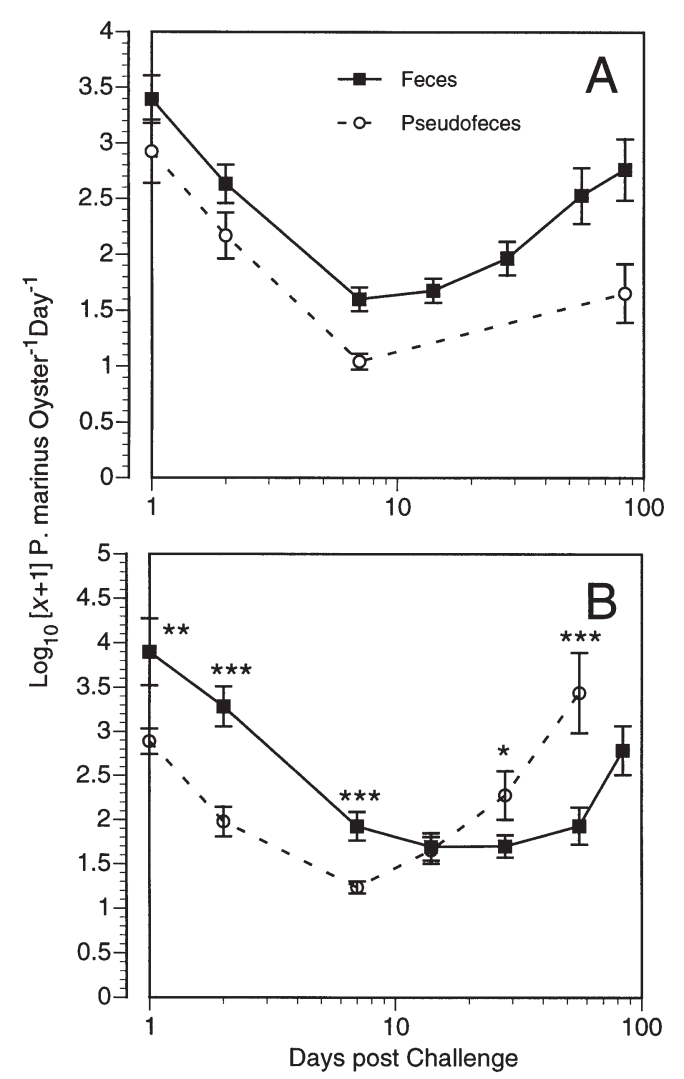

Fig. 1. Crassostrea virginica. Time course of Perkinsus marinus discharge from experimentally challenged oysters plotted according to (A) discharge compartment and (B) parasite type. Cultured ( $\square$ ) vs wild-type (O) comparison in (B) includes feces only, because pseudofeces was not analyzed on all dates. Each oyster received an initial dose of $10^{6}$ P. marinus $\mathrm{g}^{-1} \mathrm{wwt}$, which was about $8 \times 10^{6}$ cells per oyster. Error bars represent standard errors of the mean. Initially, $\mathrm{N}=40$ for each point in (A) and 20 for each point in (B), but numbers decreased thereafter due to mortality. Differences between sample means for specified collection times: ${ }^{* * *} \mathrm{p}<0.001 i^{* *} \mathrm{p}<0.01 ;{ }^{*} \mathrm{p}<0.05$; (2-way ANOVA for each time period) over the first $24 \mathrm{~h}$. Bonferroni multiple comparisons indicated that significantly fewer parasites were shed in feces and pseudofeces following intubation compared to adductor muscle injection. Compared to shellcavity injections, significantly fewer parasites were shed following intubation in pseudofeces, but not in feces. The number of parasites shed (in both feces and pseudofeces) after shell-cavity injection and adductor muscle injection were not significantly different from each other.

\section{Comparison of Perkinsus marinus elimination rates associated with in vitro culture phase}

During the first day after inoculation, the mean number of Perkinsus marinus recovered in the feces and pseudofeces ranged between $10^{7.2}$ and $10^{7.4}$ (Table 1). Analysis of variance among replicate buckets $(\mathrm{N}=3$ for each culture phase) showed that the numbers of cells discarded was statistically the same for each culture phase for both feces $(\mathrm{p}=0.608)$ and pseudofeces $(\mathrm{p}=$ 0.067).

\section{Comparison of Perkinsus marinus elimination rates associated with acute and chronic dosing}

On Day 1 post-feeding of Perkinsus marinus, there was no difference in the quantity of parasites released in the feces or pseudofeces between the chronic and acute treatments (Fig. 2). On Days 28 and 56, however, the quantity of $P$. marinus eliminated in the feces of chronically dosed oysters was about 4 orders of magnitude higher than that discharged by oysters dosed at the start of the experiment only. Discharge levels in the latter were roughly equivalent to controls (which may have had very low-level infections at the start of the experiment or become infected from laboratory water or food during the experiment). A similar pattern was

Table 1. Perkinsus marinus. Mean (SEM) densities, $1 \mathrm{~d}$ postchallenge, in the feces and pseudofeces of oysters (Crassostrea virginica) into whose shell cavity cells from 1 of 3 culture stages (lag, log, or stationary) had been injected. For each culture stage, $\mathrm{N}=3$ replicate buckets, each containing 10 oysters. There were no significant differences among groups

\begin{tabular}{|c|c|c|}
\hline \multirow[t]{2}{*}{ Culture phase } & \multicolumn{2}{|c|}{$\log _{10}[x+1]$ P. marinus $\mathrm{g}^{-1} \mathrm{wwt}$} \\
\hline & Feces & Pseudofeces \\
\hline Lag & $7.29(0.125)$ & $7.43(0.052)$ \\
\hline Log & 7.27 (0.139) & $7.39(0.093)$ \\
\hline Stationary & $7.41(0.092)$ & $7.16(0.050)$ \\
\hline
\end{tabular}


observed for the pseudofeces, but the differences between the chronic and acute treatments were only 2 orders of magnitude on Day 28 and there were no statistical differences on Day 56 (Fig. 2).

\section{Correlation of parasites in feces with total body parasite burdens and survival time}

The discharge rate of parasites in the feces of live oysters at the end of the dosing experiment (Day 84) was highly correlated with the total body parasite burdens of the same oysters, which were sacrificed that day $\left(\mathrm{r}^{2}=0.61, \mathrm{p}<0.0001, \mathrm{~N}=29\right.$; Fig. 3$)$. In addition, the number of Perkinsus marinus in the feces shed during the course of the experiment was negatively correlated with survival time $\left(\mathrm{r}^{2}=0.44, \mathrm{p}=0.016, \mathrm{~N}=12\right.$; Fig. 4).

\section{Comparison of parasite numbers discharged from live oysters with those released from dead oysters}

A rough comparison was made of the potential numbers of Perkinsus marinus discharged into the water in the feces of live oysters with that potentially released by dead oysters during a specific time period. The period chosen was a 5 mo span from mid-June through midNovember 1992, during which a population of oysters was monitored for $P$. marinus infections and mortality in Delaware Bay (Bushek et al. 1994). Monthly mean weighted prevalences were converted to mean monthly parasite burdens according to Bushek et al. (1994; Figs. 8B \& 9A). The relationship between parasite burdens and daily fecal discharge of $P$. marinus for an oyster with a wet tissue weight of $5.3 \mathrm{~g}$ was derived from results of the present study (Fig. 3) and multiplied by 3 to better approximate the size of oysters in the Bushek et al. (1994) study. A monthly discharge rate was then calculated by multiplying the average daily discharge for each month by 30 (d). Mortality began in mid-August, and about $30 \%$ of the oysters had died by mid-November (Bushek et al. 1994). The average parasite burden of dead oysters was assumed to be $10^{6}$ $\mathrm{g}^{-1}$ wwt (Ford et al. 2002). The cumulative fecal discharge for a starting number of 100 oysters over the 5 mo study period was estimated. Upon death oysters were assumed to release their entire parasite body burden into the water at once, and were removed from the category of live oysters discharging $P$. marinus into the water via feces. According to the model, the quantity of parasites estimated to be released in the feces of live oysters during this 5 mo period was $8.9 \%$ of that present in the tissues of the dead oysters and available for release into the environment.

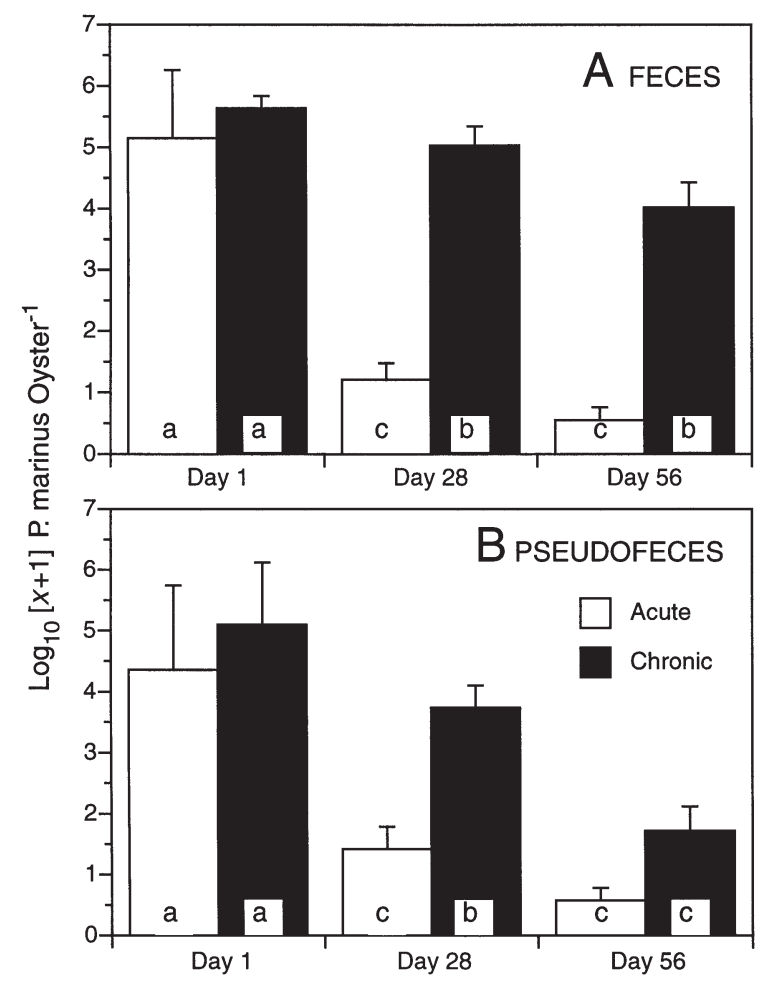

Fig. 2. Crassostrea virginica. Time course of Perkinsus marinus discharge in feces and pseudofeces of oysters challenged by feeding with $2.4 \times 10^{8}$ cultured $P$. marinus at the start of the experiment (acute) or the same quantity in 24 equal doses 3 times a week for $8 \mathrm{wk}$ (chronic). $\mathrm{N}=36$ for each experimental treatment and 18 for controls. Error bars represent standard errors of the mean; means with different letters at the base of the bar were significantly different at $\alpha=0.05$ (2-way ANOVA with time and dosing methods as factors, Bonferroni post hoc test); means with same letters at the base of the bars were not statistically different from each other

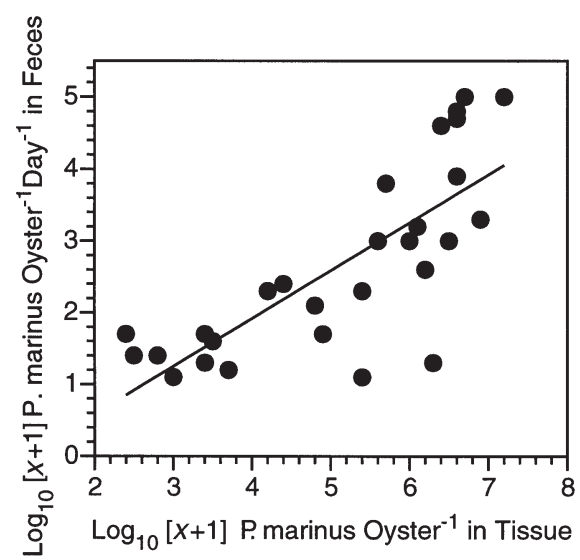

Fig. 3. Crassostrea virginica. Scattergram showing relationship between Perkinsus marinus tissue burdens in oysters and the number of parasites discharged in feces of the same oysters over preceding $24 \mathrm{~h}$. Average oyster wet tissue weight was about $5.3 \mathrm{~g}$. Oysters were assayed $84 \mathrm{~d}$ after challenge with about $8 \times 10^{6} \mathrm{P}$. marinus per individual. Regression equation: $y=0.667 x-0.752, r^{2}=0.61, p<0.0001$ 


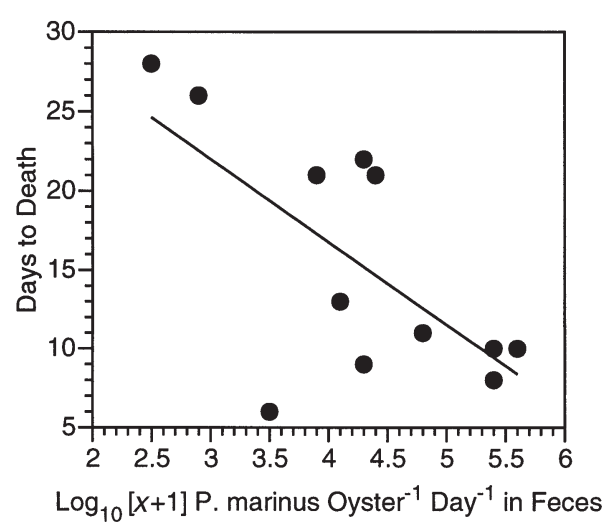

Fig. 4. Crassostrea virginica. Scattergram showing relationship between Perkinsus marinus discharge in feces and days to death. Average oyster wet tissue weight was about $5.3 \mathrm{~g}$. Each oyster received an initial dose of about $8 \times 10^{6} \mathrm{P}$. marinus. Regression equation: $y=-5.235 x+37.752, \mathrm{r}^{2}=0.44$, $\mathrm{p}=0.016$

\section{DISCUSSION}

The enumeration of Perkinsus marinus in the feces and pseudofeces of oysters after experimental dosing of parasites served 2 purposes. It supplemented the data we obtained by determining total body parasite burdens in the same oysters, and provided an additional means for interpreting the results of various challenge experiments, especially as they relate to pathogen virulence. The data also allowed us to estimate the contribution of parasites discharged in the feces to the overall transmission potential of P. marinus.

Although the total quantity of parasites eliminated from experimentally infected oysters was only a small percentage of the dose administered $(<5 \%)$, an examination of the pattern of discharge over time is informative. Parasites were eliminated in 2 distinct phases. During the first week to $2 \mathrm{wk}$ post-challenge, the rate for both fecal and pseudofecal elimination steadily declined. After a variable period of low and relatively constant discharge, the rate increased during the last part of the experiment. We interpret these phases to be a result of the 'lag' and 'log' phases of in vivo parasite proliferation, analogous to those observed during in vitro culture. That is, during the 'decreasing' phase, experimentally dosed Perkinsus marinus have yet to begin replicating to a significant degree (the 'lag' phase) and comprise the bulk of the shed parasites. The increasing ('log') phase occurs after the dosed parasites have become well established and have begun replicating rapidly. Bushek \& Allen (1996) observed a similar pattern where parasite burdens declined in oysters that died during the first few weeks after challenge with cultured $P$. marinus and then began to increase. In the present study, the apparent in vivo 'lag' time was observed in oysters dosed with both cultured and wild-type $P$. marinus. It was considerably longer, however, for the cultured cells (about 7 wk vs 2 to 4 wk for the wild-type cells), suggesting that the cultured $P$. marinus faced a more difficult adjustment to the in vivo conditions than did the wild-type cells. Given that the parasites encountered a very different environment inside the oyster than they did in culture, the longer lag time is not surprising. Whether the 'adjustment' to new conditions is through genetic selection or a physiological change in the general population, it undoubtedly contributes to the low virulence measured for cultured P. marinus (Ford et al. 2002).

A comparison of both levels and patterns of elimination in oysters injected with cultured or wild-type cells is particularly interesting. During the first week after challenge in the first experiment, cultured parasites were eliminated at a significantly higher rate than were wild-type parasites. Over the first $2 \mathrm{~d}$, when most elimination occurred, $3.6 \%$ of all cultured and $0.11 \%$ of all wild-type Perkinsus marinus were found in the feces and pseudofeces. In the second experiment, we tested the hypothesis that this difference might be due to the fact that the wild-type parasites were typically single cells, whereas the log-phase in vitro cultures consisted of cells in various stages of development, including many large mother cells (meronts) containing numerous daughter cells (merozoites). These were counted as 1 cell in establishing the injection doses; however, they would have produced multiple cells in the feces and pseudofeces if they had released daughter cells shortly after the injection. Dosing of $P$. marinus from different culture phases, with different proportions of various cell types, did not support this hypothesis; therefore, we must conclude that the difference was because of a truly higher rejection rate of cultured cells. Although the rejected number of $P$. marinus was only a small fraction of the dose administered, the 35 -fold higher number of cultured parasites rejected suggests that another factor contributing to the relatively low virulence of cultured parasites may be that cultured parasites are less able to infect oysters, either for inherent reasons or because they are selectively recognized and rejected at the gill/palp level by the host. The argument that oysters can differentiate between cultured and wild-type parasites is consistent with evidence that they can differentiate among many other particles, including various algal species (Newell \& Langdon 1996).

During the early post-challenge period, more parasites were found in the feces than in the pseudofeces, and the highest number of parasites rejected in the feces was from oysters injected via the adductor muscle sinus (about $4 \%$ of the total injected dose compared with $<1 \%$ for the other methods). In an earlier study of 
Perkinsus marinus elimination in oyster discharges, Bushek et al. (1997) observed many parasites to be inside hemocytes, and one method by which P. marinus is thought to enter and exit the host is by being transported inside hemocytes through the epithelium (Mackin 1951, Mackin \& Boswell 1955, Alvarez et al. 1992). Parasites injected directly into the circulatory system would have been in immediate proximity to large numbers of hemocytes, which may have led to rapid phagocytosis and diapedesis of parasite-laden hemocytes through the epithelia. The large number of blood sinuses surrounding the digestive epithelia may, in turn, explain the larger proportion of parasites in the feces.

Although the average number of parasites found in the pseudofeces was always less than that found in the feces, high numbers $\left(10^{5}\right.$ to $10^{6}$ oyster $\left.^{-1} \mathrm{~d}^{-1}\right)$ were being discarded in the pseudofeces of some oysters when the experiment ended on Day 84. An abundance of Perkinsus marinus in the pseudofeces is consistent with the finding by Chintala et al. (2002) of abundant $P$. marinus in the shell cavity fluid, where they could become entrained in the ciliary pathways on the gills and palps, and then sorted and eliminated. At present, it is uncertain whether these parasites had recently been shed via diapedesis of hemocytes or were actually resident and proliferating in the shell cavity. Nevertheless, their presence indicates that elimination via the feces is not the only pathway by which $P$. marinus exits the oyster host.

Oysters dosed continuously with cultured Perkinsus marinus in their food appeared to gradually lose the ability to discard parasites (Fig. 2). This diminution was particularly evident in the pseudofeces where the number of parasites eliminated decreased by 3 orders of magnitude over $8 \mathrm{wk}$, even though the dosage remained constant. The total parasite body burdens of oysters in both acute and chronic treatments were low and statistically indistinguishable from each other (Chintala et al. 2002). Therefore, the bulk of parasites shed by chronically dosed oysters came from the dosage, not from established infections. One explanation for the lessening rejection rate over time is that the parasites had become more infective; however, parasite burdens did not increase with time (Chintala et al. 2002). The general downward trend found in both treatments could be linked to the fact that the oysters were held in small volumes of water and fed only a maintenance diet so they could simply have been becoming less physiologically active. On the other hand, the decline was relatively greater in the pseudofeces than in the feces, indicating that the sorting mechanism (e.g. ciliary activity) was becoming less efficient faster than that leading to rejection via the feces (e.g. ingestion and diapedesis).
An important finding of this study was that the quantity of Perkinsus marinus shed in the feces is highly correlated with the total body parasite burden. In fact, the correlation between daily feces discharge and body burdens $\left(r^{2}=0.61\right)$ is equivalent to that between the standard Ray/Mackin tissue-subsample method for diagnosing $P$. marinus and body burdens $\left(\mathrm{r}^{2}=0.64\right.$; Bushek et al. 1994). Thus, our data suggest that collection of feces from oysters held in isolation is a potentially important non-destructive and non-invasive method for detecting the presence and relative intensity of infections. Scanlon (1997) also found a positive and significant correlation between the abundance of $P$. marinus in the feces of naturally infected oysters and the density of parasites in their hemolymph $\left(\mathrm{r}^{2}=0.38\right.$, $\mathrm{p}<0.0001$ ), however, she failed to find any correlation between total body and feces burdens in the 10 oysters that survived to the end of the test period. Most of these oysters were extremely heavily infected $\left(10^{5.5}\right.$ to $10^{7.2} \mathrm{~g}^{-1} \mathrm{wwt}$ ). A closer inspection of our data (Fig. 3) indicates that the relationship may be masked by high variability among oysters. If only those oysters with relatively heavy burdens ( $>10^{6}$ cells oyster $\left.{ }^{-1}\right)$ are examined, the relationship is not apparent. Our data suggest that variability in discharge rates increases with infection intensity, and some oysters near death or experiencing considerable infection-induced stress may not void feces or parasites at rates comparable to less heavily parasitized oysters. As with the relationships described by Bushek et al. (1994) between total parasite load and infection intensity estimates from solid or fluid tissue-samples, variability is high and identifying relationships requires large sample sizes that span the potential range of parasite burdens.

Our finding of abundant Perkinsus marinus in the feces and pseudofeces of infected oysters suggested a possibly large contribution to the transmission potential of this parasite. The data also gave us the means to estimate the possible contribution of parasites shed from living oysters during the course of infection proliferation in comparison with that from cadavers of newly dead oysters. Despite the apparently large numbers of parasites being continuously shed from living oysters, our calculations indicate that during a single season, with $30 \%$ mortality, this mechanism would provide only about $9 \%$ of the parasites present in the cadavers. A doubling of the cumulative mortality to $60 \%$, a not atypical value for a full epizootic, would reduce the proportion to about $5 \%$. Although we made a number of assumptions in this calculation, the values are so small that reasonable changes in these assumptions are not likely to change the overall conclusion that feces contribute little to the overall availability of $P$. marinus in the water column. Nevertheless, because $P$. marinus are produced in the feces before the major 
mortality period, they could be an important source of infective particles before those released from cadavers are available.

Our estimates are consistent with the findings that most new infections are acquired during the period when previously infected oysters are dying (Andrews 1988, Burreson \& Ragone Calvo 1996). With few exceptions, however, epizootiological studies that have addressed the onset of infections have relied on the standard RFTM tissue assay (Ray 1954, 1966), which routinely misses infections below $10^{4}$ cells $\mathrm{g}^{-1} \mathrm{wwt}$ (Bushek et al. 1994). Thus, neither the potential for oysters to become infected via transmission from feces, nor its ecological importance, can be dismissed. Scanlon (1997) clearly demonstrated that parasites shed in the feces are viable and infective. In her study, all experimental oysters exposed to the feces of infected individuals became infected within $20 \mathrm{~d}$. Transmission of Perkinsus marinus via feces is perhaps most important when environmental conditions such as low temperature or low salinity prevent the development of lethal infections. Under such conditions, when the presence of the parasite may not even be detectable using standard methods, shedding of small numbers of parasites from relatively lightly infected oysters over a prolonged period may lead to the introduction and spread of the parasite and set the stage for an epizootic when ambient conditions become favorable (Ford 1996).

Acknowledgements. We thank J. Gandy, K. Alcox, J. Oxley, I. Eleazar, T. Ferarra, D. Ianniello, L. Smith, C. Spruck, and R. Holley for assistance in maintenance of oysters and processing of samples; J. Heltshe for statistical consultation; and S. Benyi, R. Gobell and K. Rocha for critical review of the manuscript. This study was supported by the NOAA Oyster Disease Research Program under grants NA47FL0153 and NA57FL0042. This is publication No. 2001-20 from the Institute of Marine and Coastal Sciences at Rutgers, No. D-324056-01 of the NJ Agricultural Experiment Station, contribution number 1300 of the Baruch Institute for Marine Biology and Coastal Research at the University of South Carolina, and EPA Atlantic Ecology Division contribution number 00-092. Mention of trade names or commercial products does not constitute endorsement or recommendation for use by the US Environmental Protection Agency. Although the research described in this article has been funded in part by the US Environmental Protection Agency, it has not been subjected to Agency review. Therefore, it does not necessarily reflect the views of the Agency.

\section{LITERATURE CITED}

Alvarez MR, Friedl FE, Hudson CM, O'Neill RL (1992) Uptake and tissue distribution of abiotic particles from the alimentary tract of the American oyster: a simulation of intracellular parasitism. J Invertebr Pathol 59:290-294
Andreadis TG (1985) Experimental transmission of a microsporidian pathogen from mosquitoes to an alternate copepod host. Proc Natl Acad Sci USA 82:5574-5577

Andrews JD (1961) Measurement of shell growth in oysters by weighing in water. Proc Natl Shellfish Assoc 52:1-11

Andrews JD (1988) Epizootiology of the disease caused by the oyster pathogen Perkinsus marinus and its effects on the oyster industry. In: Fisher WS (ed) Disease processes in marine bivalve molluscs, Vol 18. American Fisheries Society, Bethesda, MD, p 47-63

Andrews JD, Hewatt WG (1957) Oyster mortality studies in Virginia. II. The fungus disease caused by Dermocystidium marinum in oysters of Chesapeake Bay. Ecol Monogr 27:1-26

Burreson EM, Ragone Calvo LM (1996) Epizootiology of Perkinsus marinus disease of oysters in Chesapeake Bay, with emphasis on data since 1985. J Shellfish Res 15:17-34

Bushek D, Allen SK Jr (1996) Host-parasite interactions among broadly distributed populations of the eastern oyster Crassostrea virginica, and the protozoan Perkinsus marinus. Mar Ecol Prog Ser 139:127-141

Bushek D, Ford SE, Allen JSK (1994) Evaluation of methods using Ray's fluid thioglycollate medium for diagnosis of Perkinsus marinus infection in the eastern oyster, Crassostrea virginica. Annu Rev Fish Dis 4:201-217

Bushek D, Allen SK, Alcox KA, Gustafson R, Ford SE (1997) Response of Crassostrea virginica to in vitro-cultured Perkinsus marinus: preliminary comparison of three inoculation methods. J Shellfish Res 16:479-485

Bushek D, Holley RA, Reece KS (2000) Use of micromanipulation and 'feeder' cultures to clone the protozoan oyster pathogen Perkinsus marinus. J Eukaryot Microbiol 47: 164-166

Cheng TC (1973) General parasitology. Academic Press, New York

Chintala MM, Bushek D, Ford SE (2002) Comparison of in vitro-cultured and wild-type Perkinsus marinus. II. Dosing methods and host response. Dis Aquat Org 51:203-216

Côté IM, Poulin R (1995) Parasitism and group size in social animals: a meta-analysis. Behav Ecol 6:159-165

Fisher WS, Oliver LH (1996) A whole-oyster procedure for diagnosis of Perkinsus marinus disease using Ray's fluid thioglycollate culture medium. J Shellfish Res 15:109-117

Ford SE (1996) Range extension by the oyster parasite Perkinsus marinus into the northeastern US: response to climate change? J Shellfish Res 15:45-56

Ford SE, Schotthoefer A, Spruck C (1999) In vivo dynamics of the microparasite Perkinsus marinus during progression and regression of infections in eastern oysters. J Parasitol 85:273-282

Ford SE, Chintala MM, Bushek D (2002) Comparison of in vitro-cultured and wild-type Perkinsus marinus. I. Pathogen virulence. Dis Aquat Org 51:187-201

Fuxa JR, Tanada Y (eds) (1987) Epizootiology of insect diseases. John Wiley \& Sons, New York

Hofmann EE, Powell EN, Klinck JM, Saunders G (1995) Modelling diseased oyster populations. I. Modelling Perkinsus marinus infections in oysters. J Shellfish Res 14:121-151

Mackin JG (1951) Histopathology of infection of Crassostrea virginica (Gmelin) by Dermocystidium marinum Mackin, Owen, and Collier. Bull Mar Sci Gulf Caribb 1:72-87

Mackin JG (1962) Oyster diseases caused by Dermocystidium marinum and other microorganisms in Louisiana. Publ Inst Mar Sci Univ Tex A\&M University 7:132-229

Mackin JG, Boswell JL (1955) The life cycle and relationships of Dermocystidium marinum. Proc Natl Shellfish Assoc 46: 112-115 
Mortensen SH (1993) Passage of infectious pancreatic necrosis virus (IPNV) through invertebrates in an aquatic food chain. Dis Aquat Org 16:41-45

Newell RIE, Langdon CJ (1996) Mechanisms and physiology of larval and adult feeding. In: Newell RIE, Kennedy VS, Eble AF (eds) The eastern oyster Crassostrea virginica. Maryland Sea Grant College, College Park, MD, p 185-229

Ragone Calvo L, Burreson EM (1994) Characterization of overwintering infections of Perkinsus marinus (Apicomplexa) in Chesapeake Bay oysters. J Shellfish Res 13: 123-130

Ray SM (1952) A culture technique for the diagnosis of infections with Dermocystidium marinum, Mackin, Owen and Collier, in oysters. Science 166:360-361

Editorial responsibility: Albert Sparks, Seattle, Washington, USA
Ray SM (1954) Biological studies of Dermocystidium marinum, a fungus parasite of oysters. Rice Institute, Houston, TX

Ray SM (1966) A review of the culture method for detecting Dermocystidium marinum with suggested modifications. Proc Natl Shellfish Assoc 54:55-69

SAS Institute (1990) SAS language: reference, Version 6, 1st edn. SAS Institute, Cary, NC

Saunders GL, Powell EN, Lewis DH (1993) A determination of in vivo growth rates for Perkinsus marinus, a parasite of Crassostrea virginica. J Shellfish Res 12:229-240

Scanlon CH (1997) The potential for transmission of Perkinsus marinus by fecal matter from the eastern oyster, Crassostrea virginica. MS thesis, College of William and Mary, Williamsburg, VA

Submitted: December 8, 2000; Accepted: February 12, 2002 Proofs received from author(s): August 29, 2002 